\title{
La visibilidad mediática de los soldados argentinos durante la Guerra de Malvinas en los diarios correntinos Época y El Litoral*
}

\author{
Luis Daniel Chao**
}

\section{Resumen}

El siguiente trabajo parte de la categoría régimen escópico de Martin Jay, para poder articularla con otras teorías que nos permitan entender el fenómeno de la visibilidad y abordar un caso particular.

Una vez construido el entramado teórico, se propone una lectura centrada en la visibilidad de los soldados argentinos durante la Guerra de Malvinas en los periódicos correntinos Época y El Litoral, en los meses que van de abril a junio de 1982. Una vez establecidas algunas regularidades, se intentará ligarlas a determinadas condiciones discursivas que puedan generarlas.

\section{Palabras clave}

Visibilidad - Guerra de Malvinas - medios de comunicación.

\section{Abstract}

The following work part of the category escopic's regime of Martin Jay, in order to be able to articulate it with other theories that allow us to understand the the visibility and address it to a particular case. Once built the theoretical framing, we propose a

\footnotetext{
* Artículo recibido 30 de abril de 2012. Aceptado 4 de diciembre de 2012.

** Licenciado en Comunicación Social por la Universidad Nacional del Nordeste, Argentina. Contacto: danichao9@yahoo.com.ar
} 
reading focused on the visibility of the Argentine soldiers during the war of Malvinas in the newspapers Época and El Litoral from Corrientes, in the months from April to June 1982. Once laid down certain regularities, will attempt to have contributed certain discursive conditions that can regenerate them.

\section{Keywords}

Visibility - Malvina's War- mass media.

El siguiente artículo parte de dos objetivos primordiales. El primero, pensar la inteligibilidad social de ciertos actores desde los discursos sociales, centrándonos en aquellos discursos cuya materialidad sígnica se sostiene en lo visual, es decir, en la imagen. Es por ello que utilizaremos categorías que nos permitan abordar la visibilidad discursiva, entendiendo a la visibilidad como las condiciones que posibilitan que determinados objetos se hagan visibles. En este punto articulamos conceptos de corte foucaultiano, como el de régimen escópico de Martín Jay, con la teoría de la institución imaginaria de la sociedad de Castoriadis y herramientas propias de la semiótica visual.

El segundo objetivo que nos plateamos, a su vez, puede partirse en dos. Intentaremos pensar la visibilidad de los soldados argentinos durante la Guerra de Malvinas, tomando como soporte a los diarios correntinos Época y El Litoral. Trataremos de marcar ciertas regularidades presentes en la visualidad de los soldados, con la intención de vincularlas con sus condiciones de emergencia. Nuestros resultados -y por eso hablábamos de una bipartición de este objetivo- nos pueden servir de base para proyectar una futura investigación: pensar la inteligibilidad de los excombatientes en posguerra. Las formas de aparición icónica de los soldados durante la guerra serán una pata necesaria para reflexionar sobre las condiciones discursivas de la visibilidad de los veteranos de la guerra del Atlántico Sur.

Se hace necesario a partir de aquí construir el campo teórico que nos permitirá pensar la visibilidad en los términos que hemos señalado. Luego abordaremos algunas imágenes con el fin de señalar las regularidades que se presentan. Por último, intentaremos ligar estas regularidades a algunas condiciones discursivas que permiten su emergencia.

\section{Régimen escópico}

Al referirnos a las imágenes emergentes en una sociedad y una época, nos adentramos al terreno de lo que Martín Jay define como régimen escópico, es decir, el modo de ver de una sociedad, ligado a sus prácticas, valores y otros aspectos culturales, históricos y epistémicos. "La particular mirada que cada época histórica construye consagra un régimen escópico o sea, un particular comportamiento de la percepción 
visual" (Jay, 2007: 222). Esta definición, en apariencia simple, nos lleva a reflexionar sobre qué es un modo de ver, qué implica, cómo se constituye, qué límites tiene y cuál es su relación con lo social.

Un modo de ver - al configurar una forma de mirar - regula, marca límites hacia dentro, habilita qué se ve, $y$, a su vez, esconde, niega, tranquea, tabuiza. María Ledesma (2005) retoma el desarrollo de Jay y amplía la definición de régimen escópico, afirmando que aquello que cada época considera verosímil respecto de lo visible conforma un modo de ver determinado. Lo verosímil para Ledesma entra en una relación recíproca con estas regularidades discursivas, ya que desde allí se habilitaría qué imágenes pueden reconocerse como verdaderas en una sociedad dada. Hablamos entonces de la normalización de un modo de mirar y de objetos para mirar en una cultura. Así tanto Ledesma como Jay coinciden en que la modernidad normalizó una mirada que solo vio objetos reales, y que el lato lugar común ver para creer es la apoteosis de la verdad y la objetividad moderna. Esta mirada normalizada supone que el régimen escópico habilita determinadas imágenes y oculta otras, estableciendo lo que es visibilizable y lo que no en una sociedad.

Lo visible desde Ledesma puede ser entendido como el conjunto de imágenes que el ojo crea al mirar, la realidad se hace visible al ser percibida. Como ya dijimos, la particular mirada que cada época histórica construye consagra un régimen escópico, o sea, un particular comportamiento de la percepción visual. El campo de lo visibilizable es la posibilidad que tiene la imagen de emerger en una sociedad y volverse visible. Son potenciales permitidos que soportan a lo visible y que dependen de la normalización de tipos de imágenes. En Claudia Rosa (2011) encontramos un espacio más para poder cercar nuestro objeto de estudio, ya que la autora entiende a la visibilidad como las condiciones discursivas que hacen que determinado objeto social sea visible. Lo visible se teje en las condiciones discursivas de producción, en lo extradiscursivo que deja huellas en la generación de discursos. Para Rosa el campo de lo visible remite a un sistema de valores que pueden ser asignados y organizados, y lo visible sería aquello que puede ser capaz de ser objeto de descripción, nombrado, clasificado.

Pero desde nuestra mirada, la definición de este régimen discursivo no nos ayuda a entender la visibilidad en un escenario situado. Es decir, al afirmar que el régimen escópico configura un modo de ver, que estabiliza objetos para ver y que se relaciona con las prácticas y valores de una sociedad, nos está faltando la espesura conceptual para poder entender realmente por qué puede operar un régimen de estas características sobre el ver, el reconocer y el representar mediante imágenes.

Por esta razón creemos que la teoría de la institución imaginaria de la sociedad de Castoriadis nos extiende el horizonte de visión. La capacidad creadora de las sociedades, la institución de significaciones sociales y de un código de uso del lenguaje nos permiten reflexionar sobre la visibilidad en una doble relación: con el régimen 
escópico que limita el uso y la aparición de imágenes y con un imaginario social siempre activo, que excede a lo icónico y permite el cambio, el movimiento y la explosión de sentidos sin referentes estables.

\section{La institución imaginaria de la sociedad}

Para darle un marco introductorio a la teoría de Castoriadis, podemos decir que este propone un complejo acercamiento a lo social, sobrepasando la idea de sistema u organismo (como sumatoria de individualidades), dándole una especificidad que no puede entenderse sino de manera inmanente. Establece la idea de sociedad como coexistencia de identidades y de relaciones entre sujetos y objetos sociales, no mediados por cosas definidas desde afuera. Cada sociedad es creadora de las identidades y de los órdenes de su coexistencia, y la articulación social se crea cada vez. Esta capacidad de creación de su propio universo de discursos, de sus tipos de relación, se da por la cualidad de lo social de instituirse como tal (Castoriadis, 1999).

Las diferentes formas de concebir las partes de la sociedad (lo legal, lo económico, lo religioso, lo moral) no son sino modos de institución particulares - dominios- de una sociedad en particular. Lo que las sociedades instituyen son tipos de articulación social, por lo que el derecho, la política, el arte, la religión son articulaciones sociales de un modo particular de institución social, que instituye su propio lenguaje e instrumentos y permite la reproducción indefinida de sus instancias (pp. 25-27).

A pesar de referirse a la capacidad instituyente de la sociedad, es decir, a la cualidad de autocrearse, el desarrollo de Castoriadis no desentiende las luchas de poder (negación de la alteridad, desconocimiento de la sociedad de su ser histórico social) e imposiciones en el interior de las sociedades, pero en su visión podemos vislumbrar la esperanza de que la capacidad autoinstituyente de la sociedad permita crearnos una realidad más igualitaria.

\section{El Legein}

Como ya mencionamos, la institución del lenguaje forma parte de la creación de las articulaciones de una sociedad. Para poder pensar el lenguaje icónico y su relación con el imaginario social, su modo de ser y la institución de un modo de ver, podemos partir de lo que Castoriadis llamó la institución del Legein. La institución de un lenguajerepresentar social necesita de la institución de un código, definido como un tipo de articulación entre objetos y relaciones (p. 95). Esto implica la institución del Legein, de una operación de órdenes en conjunto. Su operación fundamental es la designación, es decir, la individualización (separación) y reunión de signos y objetos. Esto determina lo que puede decirse, lo que es y puede ser, e instituye conjuntos que definen las propiedades que tendrán los miembros de ese conjunto. 
El representar presupone objetos definidos y distintos, lo cual sería impensable sin la institución del Legein. Identificar sus conformaciones, los modos de orden de signos, puede servirnos para develar por qué una sociedad puede distinguir signos y ver o no ver signos y objetos. El Legein fija referentes, da estabilidad y orden al conjunto (limita el distinguir y el no distinguir); no solo opera sobre el nivel del código del lenguaje, sino también sobre el orden en conjuntos, en el uso, en la univocidad del uso del lenguaje, y por eso puede ordenar al mundo. Para Castoriadis la sociedad debe instituir signos para existir y darse existencia, hacerlos identificables, poder reunirlos y designarlos, instituir formas de decir y de mostrar que se estabilizan. Para que haya comunicación social y pensamiento es necesaria la equivalencia en cuanto al uso del lenguaje, que mediatiza el acceso a las significaciones. Es decir que la sociedad instituye su decir/representar, que incluye imágenes, figuras, objetos, signos diferentes e idénticos, que le permiten establecer lo que es y no es, lo que vale y no vale. Trataremos de abordar mejor este tema para poder relacionarlo con las categorías que implican el orden de la visibilidad.

\section{Aspectos del Legein}

La designación es la operación esto se llama del Legein, que implica al signo (esto se llama $X$ supone que es distinto de otros $X$, pero a su vez que es tipo, por lo que todo $X$ es signo, es decir que hay genericidad del signo, en cuanto su uso como tal) y al objeto (también definido como separable del resto). Esto es la relación signitiva entre signoobjeto, que son puestos como copartícipes. Esta relación da existencia a sus términos, pone en juego la representación y su funcionamiento es institución social. El signo no puede ser signo de $X$ si $X$, como objeto, no ha podido delimitarse. Pero esta delimitación no es posible mientras no esté asociado a un signo. Es decir que $X$ (el objeto) se delimita como índice de sí mismo, se abre y hace posible asignaciones ulteriores que lo tienen como referente. En el mismo nivel se encuentra el signo, que para ser reconocido debe ser identificado como signo y como este signo (pp. 99-138).

Este punto es importante para poder entender cómo se instituye un modo de representar y relacionar signos y objetos en una sociedad. La relación signitiva es el primero de los esquemas operadores del Legein señalados por Castoriadis, que implica circularmente al esquema operador de la discreción-separación (signo y objeto deben ser separados de todos y entre ellos) y a su vez de la reunión (de todo lo que pertenece al signo, reunión de todo lo que pertenece al objeto, reunión de la pareja signo-objeto, donde el signo es signo de este objeto, y este objeto es objeto de este signo). La reunión implica la coparticipación que se define, en cuanto al objeto, coparticipación de tales aspectos, cualidades, propiedades, y en cuanto al signo, de tales formas (esquema operador del en cuanto a...). La relación signitiva no es construida por los esquemas 
operadores, se presuponen o están en inherencia recíproca, se puede separar-reunircoparticipar porque puede designarse, pero los esquemas pueden generar otros $\mathrm{X}$.

Para que estos esquemas tengan existencia es fundamental el esquema de la regla, cuya operación se define como este signo debe designar este objeto y este objeto debe ser designado por este signo, fundamento de la regla-norma. Pero aquella solo puede fundarse sobre las necesidades del Legein instituido. Usar el lenguaje -lingüístico o icónico- no es asociar, sino unir y reproducir signos en tanto signos de... según normas sociales instituidas.

La relación signitiva implica además el esquema del valor o el valer, es decir, valer como (mismo valor que) o el valer para (como un fin). Valer como implica una equivalencia entre las formas: mismo signo-mismo objeto. En los signos fundan las relaciones asociativas. Valer para implica un funcionamiento por combinatoria y funda relaciones sintagmáticas. Valer como y para plantea usos del signo y del objeto en una combinación particular, valen como signos y sirven para designar. En el valer para va implicada la existencia de lo que designa, vale para ser usado en el discurso (pp. 143150).

Por estos esquemas, en y por el Legein, se instituye una jerarquía (red jerarquizada) de signos y combinaciones de signos de diversos órdenes en correspondencia con un seudo-mundo identitario codificado por estos signos y formado por objetos distintos y definidos, así como por las relaciones distintas y definidas entre estos objetos. En esta red se instauran dominios particulares donde los esquemas funcionan dando existencia a especificaciones particulares: "reglas de pertinencia, contenido relativo al dominio en cuestión" (p. 155). Por ejemplo, la institución de la prensa es institución de objetos y relaciones y no puede cobrar realidad si no es institución específica de Legein periodístico.

Para Castoriadis ser y valer en el Legein significan lo mismo: es signo porque vale como signo, y a su vez, es objeto porque vale como objeto. El Legein da existencia al valor, implica entendimiento $y$, a su vez, la relación signitiva que el entendimiento no puede construir ni producir. La institución histórico-social de este aspecto codificado clausura, pone barreras, pero a su vez da los recursos para alterarla: disponer del esquema de la relación signitiva es disponer de esta posibilidad de nombrar, de mostrar, de significar por doquier.

Al instituir la forma en que se da la relación entre el signo y el objeto, bajo qué reglas se reconocen como tales, cuál es su valor dentro del discurso y dentro de qué dominios de lo social funcionan, podríamos decir que el régimen escópico, según la primera definición abordada, correspondería al Legein del lenguaje icónico. Sin embargo, aunque esta definición no sería del todo incorrecta, aún falta una parte importante para poder entender el régimen de visibilidad en funcionamiento. Ya que, si bien las limitaciones y habilitaciones de un modo de ver, el reconocer y representar mediante imágenes se dan en el Legein (es decir, en el código y el uso social), aún no 
podemos entender la idea de potencialidad de lo visibilizable y la alteridad del régimen escópico. Para ello es necesario avanzar en el desarrollo conceptual de Castoriadis y adentrarnos en lo que él llamo las significaciones imaginarias sociales (Castoriadis, 1999: 132), que exceden a la cualidad de código y uso del Legein, y que son la institución fundamental de las sociedades.

\section{Las significaciones imaginarias sociales}

Castoriadis afirma que cada sociedad define su propio universo discursivo, establece a cada momento lo que es y no es. Ser es significar y todo tiene significado en la sociedad (hasta lo insignificante); el no-ser es para ser negado. La institución de la sociedad es institución de un mundo de significaciones, o para ser más precisos, del magma de significaciones. ${ }^{1}$ El imaginario social es creación de significaciones y creación de soportes de esas significaciones; es la posición de un magma de significaciones imaginarias $\mathrm{y}$ de instituciones que las portan $\mathrm{y}$ las transmiten. Es el modo de presentificación de la imaginación radical (la capacidad de autoinstituirse de las sociedades) en el conjunto, produciendo significaciones que la psique no podría producir por sí sola. Las significaciones imaginarias son la instancia de creación del modo de una sociedad, dado que instituyen las significaciones que producen un determinado mundo (griego, romano, incaico, etc.) llevando a la emergencia de representaciones, afectos y acciones propios. Se deben diferenciar del término homónimo que habitualmente circula, y que es sinónimo de representaciones sociales (pp. 283-290).

La significación considerada en su plenitud no podría descomponerse, por su naturaleza en forma de magma, pero solo puede haber comunicación si se deja aprehender como distinta y definida, como conjuntos ordenados para su uso. La significación plena es un haz indefinido de remisiones interminables a otra cosa, no se cierra sobre sí, está abierto, permite moverse al igual que el magma. Pero a la vez, la institución del Legein instituye que tal significación deber remitir a tal cosa. He aquí una compleja relación que intentaremos aclarar y relacionar con nuestras categorías de análisis. Lo visibilizable y el régimen escópico, tal como lo venimos configurando, entran en tensión por estos aspectos que interceden en el lenguaje.

\footnotetext{
1 La naturaleza magmática de las significaciones sociales refiere a la totalidad de significaciones en una sociedad, las cuales no podrían ordenarse en conjuntos ni reconocerse pues son indefinidas indeterminadas e infinitas. Sin embargo, y por la institución del Legein, desde ese magma de significaciones se pueden extraer todas las organizaciones del decir y hacer social. Las representaciones del Legein tienen al magma de significaciones sociales como su fuente de remisión, pero a su vez están limitadas por su funcionamiento como código. El magma como categoría es una de las más complejas conceptualizaciones de Castoriadis, y su definición tiene que ver, por un lado, con un corte a la concepción sistémica de la significación, y por otro, con el modo en que el psicoanálisis ve el funcionamiento del inconsciente. Esta mirada general se encuentra en todas las menciones de Castoriadis al magma de significaciones sociales, pero sobre todo puede encontrarse en el apartado "Las significaciones imaginarias sociales y la 'realidad'"' (Castoriadis: 301-310).
} 
La institución de la sociedad es en cada momento institución del magma de significaciones imaginarias sociales: un mundo de significaciones, el mundo, su mundo.

El Legein es la dimensión conjuntista del decir, es código, se presenta en el lenguaje. Pero este no es solo código, también lleva referencia al magma. Un sistema no puede cerrarse a sí mismo, el lenguaje debe decir, y en el código no hay nada que pueda postular el mundo. Para Castoriadis la significación es un haz indefinido de remisiones interminables, y en el caso de las imágenes, el significado pleno es todo lo que a partir del ícono se puede decir, pensar, hacer o representar socialmente: "el magma se mueve y permite que el lenguaje se mueva también" (p. 157). Esto le otorga cierta libertad a las significaciones y está ligado a la concepción de la autocreación de significaciones por parte de la sociedad, lo que permite la alteridad de signos y objetos y su relación.

La significación en una lengua es magma, no son elementos de un conjunto sometidos a la determinidad como modo de ser. Pero el haz de remisiones no es haz cualquiera, o cualquier remisión, el esquema en cuanto a... conduce el uso del sentido de alguna manera, su sentido es abuso de lenguaje, el sentido no está acabado en sí mismo (no hay denotación por oposición a connotación). Toda expresión es trópica (retórica, figurada), nada tiene sentido acabado, pero sí existen referencias identitarias aprehendidas del magma de significaciones. El en cuanto a... está siempre presente, pero el análisis no puede agotarlo. Entonces $X$ cubre a la vez un término de referencia en cuanto al uso y una significación que remite a una indefinidad de otras significaciones.

Las significaciones imaginarias sociales tienen un modo de ser originario, es en ellas y por ellas que existen objetos y referentes. Hay significaciones centrales o primeras instituidas-instituyentes que son creadoras de objetos y organizadoras del mundo. Las significaciones centrales instituyen referentes y objetos de representaciones individuales y organizan el mundo que las rodea. Crean actividades sociales y objetos que por fuera de estas no tendrían razón de ser. Solo es a partir de aquí que se puede hablar de significaciones que se encuentran agregadas a objetos de existencia independiente de ellas. Las centrales no son significaciones de algo (ni agregadas o referidas a algo), dan existencia a la coparticipación de objetos, actos, individuos en apariencia heteróclitos. Estas significaciones no tienen referentes, instituyen un modo de ser de las cosas y de los individuos como referidos a ellas. Decir que tal objeto es $X$ es decir cómo la sociedad trata a ese objeto. En tanto tales no son necesariamente explícitas para el grupo social que las instituye, son presentificadas, figuradas por medio de la totalidad de las instituciones explícitas de la sociedad y la organización del mundo a secas y del mundo social que ellas instrumentan. Condicionan y orientan el hacer y el representar social, en y por los cuales continúan ellas alternándose.

Es esta institución de las significaciones la que plantea el ser-no ser, valer-no valer y cómo se instauran las condiciones de lo factible y lo representable por las que se mantienen unidos individuos, objetos, funciones e instituciones. La creación de la 
sociedad instituyente como sociedad instituida es en cada momento mundo común: posición de individuos (de sus tipos, relaciones y actividades) y posición de cosas (tipos, relaciones y significados) aprehendidos en los marcos referenciales instituidos como comunes. Es institución de un mundo donde lo que es tiene sentido, pero este puede escaparse (ser lo que todavía no es). Las significaciones imaginarias no solo operan en el es/no es, vale/no vale, factible/no factible, también son presencia del no ser, de lo falso o ficticio, de lo posible pero no efectivo. Es decir, del total de la realidad constituida para una sociedad.

\section{Régimen escópico y la institución imaginaria de la visibilidad}

Podemos separar del desarrollo de Castoriadis dos aspectos de lo imaginario social y su relación con el lenguaje. Tenemos por un lado el Legein, la dimensión conjuntista del lenguaje, y por otro el magma de significaciones imaginarias sociales. ¿Cómo podemos redefinir nuestras categorías iniciales a partir de la teoría de la institución imaginaria de la sociedad?

El Legein, como todo código, codifica; estabiliza el uso, ordena las remisiones encauzando el sentido. Permite el entendimiento y la comunicación mediante sus operadores principales (la designación, la relación signitiva, la separación y reunión, la coparticipación, la regla-norma, y el valor/er). Tiene una función prescriptiva, instituye modos de representar, relacionar, entender y comunicar. Es la dimensión identitaria del hacer/representar social.

Pero el Legein no significa, no da lugar a pensar la alteración ni alumbra la relación entre un régimen discursivo y el imaginario social. Es desde el magma de significaciones imaginarias sociales donde se crea el decir y el representar instrumentando al Legein. Las significaciones centrales instituyen al mundo, crean objetos, crean sujetos y crean referentes. Son sus propios referentes, no remiten más que a sí mismas. Decir que un objeto es $\mathrm{X}$ equivale a decir cómo la sociedad trata a ese objeto, cómo ha sido creado socialmente. Lo posible y lo no posible, lo visible y lo no visible, es instituido en las significaciones imaginarias sociales, y crean al mundo. El magma no puede ser encerrado en una categoría como régimen escópico, porque está siempre en movimiento como fuente de remisión.

El régimen escópico es un modo de ver (institución del imaginario social), el Legein en el lenguaje icónico es lo que delimita la representación mediante imágenes. Pero lo visibilizable, la posibilidad de ser mostrado, es decir, la potencialidad de lo icónico de emerger en una sociedad, se estabiliza desde el valer para del Legein y se instituye por el magma de significaciones imaginarias creadas desde el imaginario social. Hay una posibilidad de uso (posibilidad de usarlo para...) y una posibilidad de existencia condicionadas por las significaciones imaginarias sociales. El Legein delimita y ata los 
reenvíos, esto es posible porque puede ser aprehendido del magma de significaciones imaginarias sociales.

El régimen escópico estabiliza objetos, signos y referentes. Lo visibilizable como potencialidad emergente, como posibilidad de que signos y objetos se reúnan y muestren, forma parte de estas estabilizaciones. Pero esta codificación no es determinada de una vez, ya que esto no permitiría la alteración de lo que puede ser representado. Esta alteración se da porque lo que se representa socialmente tiene como fuente de remisión constante al magma de significaciones imaginarias sociales que da lugar a que puedan instituirse otros decibles y mostrables - aunque no de una manera totalmente libre, pues esto equivaldría a la destrucción del entendimiento-. Lo que puede mostrarse a nivel social existe porque el imaginario social lo ha instituido y ha instituido las maneras en que puede emerger y relacionarse con otros signos. La institución de un modo de ver es inestable y por ello puede modificarse a cada momento, crearse cada vez, auto-instituirse. Lo visibilizable se vuelve fundamental ya que la remisión está ligada y libre a la vez, es el fenómeno donde buscar la relación entre imaginario y régimen escópico.

La percepción de imágenes tiene su base en esta estabilización, desde la cual se nos instituye una mirada ligada a la forma de funcionamiento del lenguaje icónico a nivel social. Estos aspectos de lo visible tienen una ligazón con las significaciones imaginarias, sobre todo aquellas que -como la significación DIOS- pueden crear todo un orden alrededor. Nuestra intención con este desarrollo fue fundamentar teóricamente la relación que tiene lo indeterminado y el sentido encauzado, ya que las imágenes emergentes en una sociedad pueden disparar disímiles sentidos, pero tienen un funcionamiento regular. Este campo teórico abierto desde Jay nos posibilita pensar por qué pueden relacionarse tipos de imagen con tipos de referente, y servirnos para un acercamiento a lo icónico como discursividad social en una situación particular. El problema surge cuando queremos pensar un dominio de lo social como el periodístico, y un objeto complejo como la representación de los soldados argentinos en la Guerra de Malvinas. Para ello debemos cercar aún más nuestro marco teórico.

\section{Régimen escópico y discurso periodístico: la visibilidad mediática}

La red jerarquizada de signos que organiza el Legein se corresponde con un seudomundo identitario codificado por estos signos. En esta red se instauran dominios particulares donde los esquemas funcionan dando existencia a especificaciones particulares (reglas de pertinencia, contenido relativo al dominio en cuestión). Entenderemos entonces a lo periodístico como uno de los modos de institución particular que instituye su propio lenguaje (lingüístico e icónico) e instrumentos, sus géneros y sus características estilísticas. Es a partir de esta idea que podemos trabajar la 
iconografía de prensa, relacionando al régimen escópico con los enunciados estabilizados del género propio de la prensa escrita.

Para Bajtin (1995) las esferas de la praxis social estabilizan sus tipos de enunciados. Una función determinada (como la periodística) y unas condiciones sociales determinadas estructuran géneros discursivos, es decir, "tipos temáticos, composicionales y estilísticos de enunciados determinados y relativamente estables" (Bajtin: 255). La teoría de los géneros discursivos de Bajtín nos es útil en esta instancia, pero desde nuestra perspectiva, en línea con el planteo de Castoriadis, diremos que tanto las esferas sociales como los géneros discursivos son parte $-\mathrm{y}$ entran en inherencia recíproca- de la institución de un modo de ser social, que instituye en cada uno de sus dominios un modo de uso (codificado) del lenguaje.

A partir de allí podemos hablar de estabilización de enunciados como de sus objetos, temas, composición y estilo dentro de un género discursivo como el de la prensa escrita. Al incluir en su organización discursiva tanto al decir como al mostrar, el género discursivo periodístico entra en relación con el régimen escópico. Pero como en cada dominio se organiza una particular jerarquía de lenguaje, podemos decir que en cada género discursivo opera un régimen de visibilidad que estabiliza tipos de imágenes de acuerdo con el dominio de lo social que le corresponda. De esta manera en cada género discursivo se crea un modo de ver y representar mediante imágenes.

\section{Los soldados de Malvinas como objeto discursivo}

Este constructo teórico nos da el marco para poder pensar un abordaje particular. En nuestros objetivos iniciales nos planteamos reflexionar sobre la visibilidad de los soldados argentinos durante la Guerra de Malvinas en dos matutinos correntinos. Creemos que a partir de la noción foucaultiana de objetos discursivos trabajada por Narvaja de Arnoux (2009), podemos abordar metodológicamente nuestro corpus. Afirma la autora: "los objetos son uno de los elementos, junto con las modalidades de enunciación, conceptos y elecciones temáticas (que forman parte de las) regularidades que se pueden reconocer en los discursos, entendidos como prácticas localizadas históricamente (...). Las condiciones de aparición de un objeto (para que se pueda decir algo de él y para que varias personas puedan decir cosas diferentes de él) son, entonces, históricas (...). Su existencia está sostenida por un 'haz complejo de relaciones'. Estas se hallan establecidas 'entre instituciones, procesos económicos y sociales, formas de comportamiento, sistemas de normas'... " (p. 67).

Desde la mirada de Narvaja de Arnoux, "el discurso es creación de sentido y construye para ello objetos de pensamiento a partir de la significación de los términos de los cuales se sirve". A estos objetos remiten y dan forma "conjuntos de expresiones nominales, predicados, deícticos, anafóricos agregados parcialmente estructurados (...) que se enriquecen progresivamente, gracias a las operaciones que el sujeto realiza con 
elementos nuevos (...). Estos objetos (...) anclan (a su vez) en preconstruidos culturales, propios del dominio al cual convoca el objeto, que dan lugar a cadenas de expectativas que pueden afianzarse o modificarse, ya que el enunciador apela a un doble mecanismo de asimilación y acomodamiento: asimila los contenidos ya existentes y los acomoda a lo que tiene intención de decir" (p. 69).

Estos objetos discursivos "pueden ser concebidos también como lo que está en juego, es decir, lo que en un momento y en una situación dada reviste una significación para las instancias del proceso comunicacional", y su permanencia se destaca por "la repetición del lexema o de sus sustitutos, el despliegue de los predicados en series continuas, la insistencia de determinados atributos, los variados modos de reformulación, el detenimiento en la oposición a otros objetos, la morosidad descriptiva y el resalte de la posición textual que se le asigna" (p. 70).

En el análisis, debemos detenernos en las secuencias en las que aparecen el lexema, sus sustitutos, los atributos que claramente remiten a aquel, los predicados con los que se asocia, las partes que se le reconocen, los otros objetos a los que se opone o con los que se enlaza, la voces que lo cobijan, los recorridos que lo privilegian. Es decir que atendemos a los lugares de la cadena en los cuales la representación tiende a estabilizarse.

La noción de objeto discursivo nos permitirá abordar el interdiálogo entre las imágenes de los matutinos elegidos, para identificar las características que tienden a regularizarse en las imágenes de prensa. Nuestro objeto de estudio son las imágenes de los soldados de Malvinas, y la lectura que haremos de las imágenes se concentrará en su nivel de enunciado, es decir, en los mundos posibles ${ }^{2}$ que conforman las imágenes, más allá de su funcionamiento enunciativo particular. La categoría semiótica de mundo posible nos servirá como correa de transmisión para identificar el lugar que ocupan los soldados de Malvinas en los medios mientras transcurre la guerra. Creemos que este tipo de lectura es la más apropiada, de acuerdo con el marco teórico que hemos construido, es decir, la articulación entre significaciones sociales como condiciones discursivas, el régimen escópico como modo de ver epocal y el género discursivo como espacio de estabilizaciones cerrado a una práctica discursiva particular. Daremos paso a una caracterización de los medios elegidos, para luego realizar el análisis propuesto.

\footnotetext{
$2 \quad$ Para Escudero (1996) lo que pone en circulación el sistema de información es la puesta en marcha de mundos posibles que suministran al lector un conjunto de informaciones simplificadas y estereotipadas que presuponen un trabajo de selección, interpretación y ensamblaje. Estos mundos posibles mediáticos, de acuerdo con el reconocimiento social de los medios de comunicación como dueños de lo verdadero, lo actual y lo real, se instituyen y son reconocidos como "la realidad" que debe ser mostrada por los medios por su calidad de espejo social. En este punto todas las estrategias de verosimilitud estabilizadas por la prensa se ponen en marcha a través de los mundos posibles.
} 


\section{Diarios Época y El Litoral}

Época es un producto de la empresa Editora Correntina, fundada por Julio Romero durante su paso por la gobernación provincial. El diario comenzó a circular el 31 de diciembre de 1973. Una vez depuesto el gobierno de Romero por los militares que asumieron la gobernación con el Golpe de 1976, el medio fue clausurado un mes y luego continuó editándose sin interrupciones. Actualmente es uno de los diarios más vendidos y con mayor porcentaje de espacio destinado a publicidad. Se encuentra intervenido ante la irresolución de un conflicto judicial entre los sucesores de Julio Romero.

Por su parte, El Litoral fue publicado por primera vez el 3 de mayo de 1960. En este caso, la empresa fue fundada por Juan Romero, tío del dueño de Época y padre de dos dirigentes políticos del partido Autonomista en Corrientes. La empresa quedó muy pronto en manos de Carlos Romero Feris, otro de los hijos de Juan, quien la dirige hasta la actualidad.

Así como Época se identificó históricamente con el Partido Justicialista en la provincia y apuntó principalmente a lectores de las capas medias, El Litoral se relacionó directamente con el Pacto Autonomista-Liberal, alianza electoral de tradición conservadora que alternó a sus candidatos por décadas en la gobernación de Corrientes.

\section{Análisis de un mundo posible: los héroes de la gesta}

A partir del 28 de marzo los diarios fueron acrecentando su información sobre el problema desatado en las islas Georgias. Se hablaba de "máxima tensión" o de una situación "agravada", incluso algunas imágenes mostraron buques de guerra en el momento en que ambos países enviaron parte de su flota a la defensa de la zona. El 30 de marzo el problema se diluyó un momento virando hacia la Plaza de Mayo de Buenos Aires y el enfrentamiento entre la policía y los miembros de la Multipartidaria. Tomando al $1 .^{\circ}$ de abril como punto de partida, podríamos decir que la guerra estaba creándose como posibilidad para los medios y sus lectores. Las secciones nacionales e internacionales centraron su referencia al conflicto y las noticias sobre las decisiones de la Junta y el gobierno inglés se expandieron en cantidad. A partir el 3 de abril la noticia ya era conocida por todo el país, y los medios correntinos comenzaron a volcar sus recursos para representar una guerra a la que miles de comprovincianos irían y la cual se desarrollaba en un lugar desconocido - pero reconocido y apreciado como argentino- (Guber, 2001).

La tapa del 3 de abril de El Litoral nos da la primera mirada sobre el soldado argentino y su acción patriótica. Cuatro soldados clavan la bandera argentina sobre la tierra redimida, recuperan aquello que fuera arrebatado hace 149 años por los 
colonialistas ingleses. La foto nos lleva directamente a una similar escarbando sobre la imaginería bélica del siglo XX: la fotografía de Joe Rosenthal sobre los soldados estadounidenses plantando la bandera de su país sobre el monte de Iwo Jima. Ambas imágenes, tomadas desde diferentes ángulos (la de Rosenthal toma a los soldados desde el costado con la bandera contraída, mientras la argentina los enfoca de frente con la bandera desplegada a lo largo), son, en algún sentido, homólogas. La fotografía argentina abre de esta manera un mundo posible, el de los soldados, que se irá nutriendo y transformando, y desde el cual podemos pensar la visibilidad de la guerra propiamente dicha (es decir, el enfrentamiento armado entre dos partes). Pero esta foto no solo es generadora, sino que es genérica, muestra un ideal de soldado en el cual la acción de plantar la bandera parece un truco propagandístico, una foto posada, que introduce una primera entrada de sentido para concebir al héroe: esto es la gesta nacional, la reivindicación, la repatriación de Malvinas, la lucha contra la colonia, y de esta forma nuestros héroes han entrado en la historia.

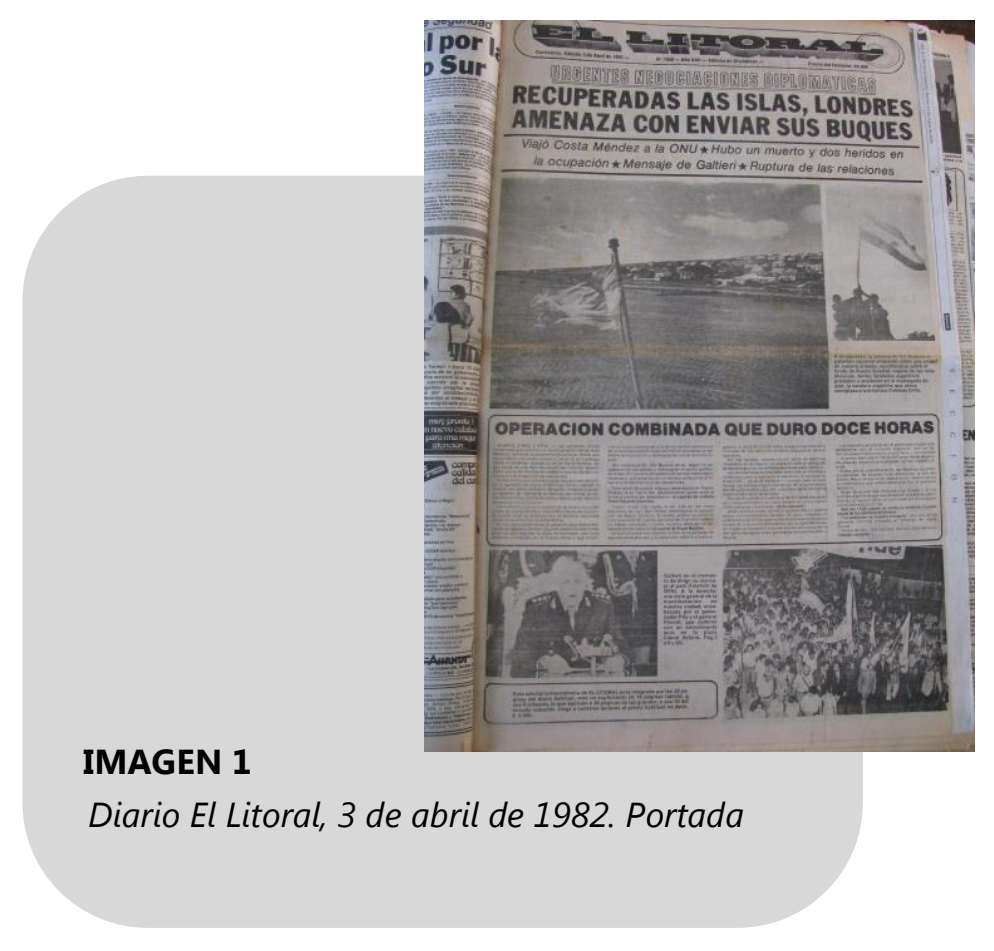

El diario Época, por su parte, suma atributos sobre esta línea. Coloca en la edición del 3 de abril una imagen que se enlaza con la que hemos visto en El Litoral. Esta vez son los soldados argentinos ingresando por mar en la costa malvinense. Se puede identificar en la foto a los efectivos junto a vehículos anfibios de guerra, por lo que el marco de la épica aparece más completo. Esta ya es una imagen de guerra y de preparación para ella, y el lector correntino ya está abriendo su marco interpretativo y el régimen escópico empieza a cercarlo. 
Los primeros días son de acomodamiento y ligazón temporal de la imagen al presente de enunciación; en medio de la algarabía social, el soldado se va haciendo espacio en el entramado iconográfico. El soldado se caracteriza por aparecer siempre en tapa, pero no en gran volumen. El 4 de abril dos portadas similares en forma pero de referentes distintos irrumpen: dos filas de soldados marchan en direcciones y hasta destinos —desde una idea épica - diferentes. Época nos muestra los marines ingleses derrotados, sus miradas perdidas esquivan la cámara. El ingreso del inglés es en forma denigrante, no hay hidalguía en sus ojos, no hay orgullo. La foto es de una simpleza pasmosa, de una lectura que no necesita reojos. Lo que vemos es la imagen del perdedor con el peso de su derrota en la mirada y la marcha. El inglés —enemigo y Otro- está marcado por la espada argentina, y la pompa de su historia colonialista (la imagen de página cuatro donde Rex Hunt —exgobernador designado bajo el mando británico- posa con su traje ceremonial militar es ejemplo de esto) pierde fuerza cuando una lucha es justa.

Por su parte, El Litoral muestra la antítesis de su colega, presentando una fila de soldados argentinos a punto de embarcarse hacia Malvinas. Sus facciones no son heroicas, más bien nos muestran seis jóvenes rostros. Miran a la cámara, incluso uno saluda con la mano, mellando de cierta manera a ese heroísmo de la primera tapa. El pulgar arriba del tercer soldado como una instantánea familiar hace ruido comparándola a Iwo jima o a la imagen que utilizará el día siguiente El Litoral en su página cuatro.

En los primeros tres días, los enunciados visuales referidos a los soldados mantienen una cierta homogeneidad con el texto escrito. La relación temporal de ambos es la misma, y texto/imagen funcionan apoyándose mutuamente. El 5 de abril ambos presentan a los soldados en la pose que los marcará hasta casi el final de la guerra: la guardia, la vigilia y la práctica. Los áridos paisajes sureños mezclados de soldados que esperan y practican, alertas y a salvo. Malvinas - la isla como geografía que incluye paisaje natural y urbano- hace su entrada. Se ven edificios, comercios, calles, autos. Los soldados pueblan, argentinizan estos espacios otrora británicos. Se habla de lo que se ve, lo que se ve es de lo que se habla; la relación básica de la verosimilitud periodística apoyada en la imagen tiene - en cuanto a la visibilidad de los soldadosuna corta existencia. Los soldados mantienen una tranquila primera estadía en Malvinas. 


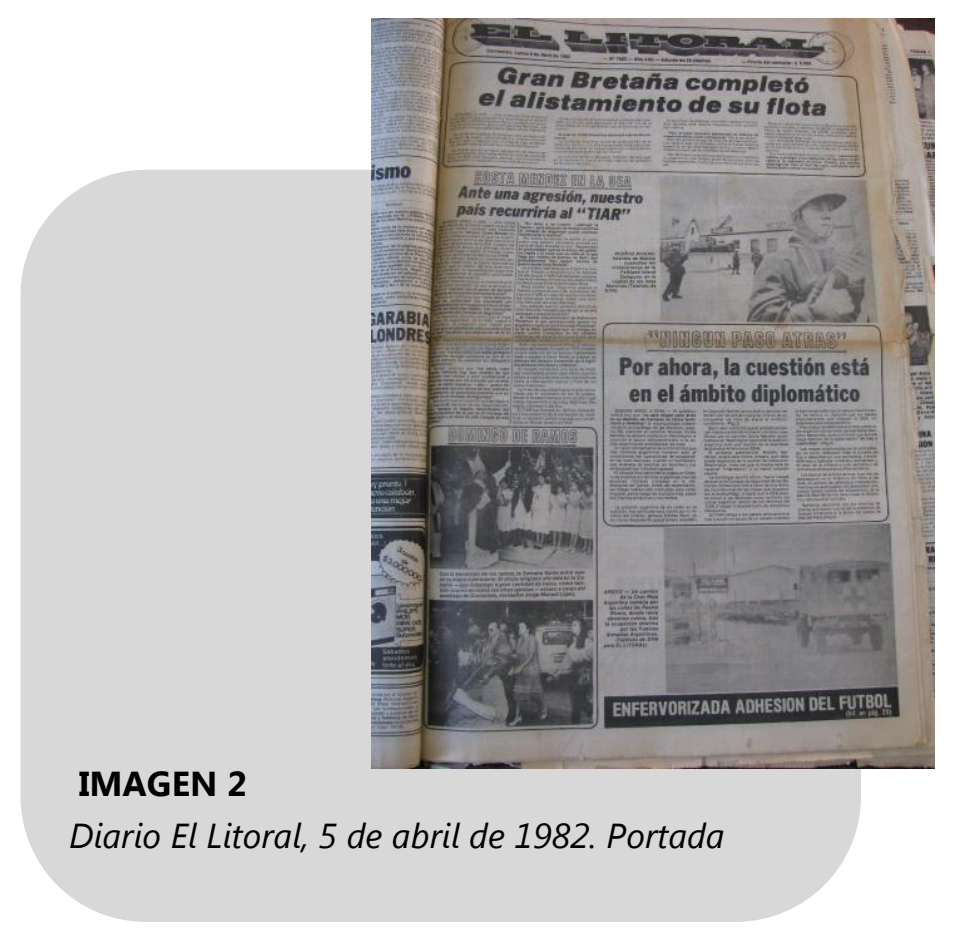

A partir del 6 de abril irrumpe en la guerra la disputa diplomática entre Gran Bretaña y Argentina que atraerá la atención durante poco más de un mes. Es en ese mundo posible donde se estrecha la relación enunciado visual, enunciado lingüístico y momento de enunciación. Las reuniones y discusiones entre diplomáticos se mostrarán prácticamente en vivo. Titulares, cuerpo de texto y fotografías conformarán una unidad homogénea de necesariedad. En cambio, el mundo posible de los soldados postula un espacio-tiempo propio que queda congelado en el frío malvinense. Generalmente en tapa, estas imágenes rodearán de soldados al desarrollo de las noticias. La tapa de Litoral nos muestra la imagen de Costa Méndez — canciller argentino en 1982hablando para los miembros de la OEA, con el título "El canciller expuso la posición argentina, dispuesta a negociar". Un poco más abajo en la página, una hilera de soldados sentados en el suelo, descansando, con sus pertrechos ordenadamente desparramados por el piso. El título reza, "Navega la flota inglesa hacia las islas Malvinas". Lo visual se divorcia de lo verbal, o simplemente los une un indeciso epígrafe - veremos por qué- que en ocasiones contradice, en otras ancla y en otras describe la imagen. En los días siguientes la estadía argentina en las Islas fue estereotipándose, de esta manera el lector correntino va completando su interpretación del lugar de los soldados en Malvinas.

Esta primera parte del mundo posible visual sobre los soldados argentinos es fundamental para el resto del análisis. El 25 de abril la flota inglesa recupera las islas Georgias y el enfrentamiento bélico entre los dos países es inminente. En este punto la homogeneidad del mundo posible empieza a resquebrajarse, y aparecen 
transformaciones, nuevas entradas y virajes que necesitan de esta primera etapa identificada para darle un marco descriptivo más completo.

Hasta el arribo de la Royal Navy no hubo grandes modificaciones al mundo posible, pero sí enriquecimiento, reforzamientos y repeticiones. Pudimos ver las maniobras y guardias de un sonriente soldado argentino en un paisaje árido -empieza a mezclarse Comodoro Rivadavia con Malvinas, es el epígrafe el que da la locación- o en una pequeña y despoblada ciudad. Vimos sus uniformes, su equipo y sus vehículos militares. La repetición de la guardia y las maniobras militares formó una temporalidad expectante. Los vemos solitarios o en grupos, conviviendo con los ciudadanos, comprando, cocinando o descansando. Saludando a la bandera o frente una cruz improvisada. Ese soldado aguardaba la solución diplomática o el inicio de la guerra, pero lo visible es esa espera. Con el control inglés sobre las islas Georgias y —unos días después- el hundimiento del buque argentino ARA General Belgrano, surge el interrogante sobre la postura del soldado de la patria. Este soldado guardián de la espera ¿se moverá?

\section{Georgias y el hundimiento del Belgrano, dos puntos de inflexión}

El 26 de abril, un día después del desembarco inglés sobre las Georgias, los diarios El Litoral y Época despliegan sus tapas con titulares, imágenes y marcas turbulentas. Pareciera que el curso de la guerra se ha modificado. El diario Época presenta en su portada una infografía, con un mapa-temático, donde acomoda —como en el juego de mesa TEG (técnicas y estrategias de guerra) - las piezas de ataque inglés y defensa argentina. La guerra tiene una primera marca de drama. Resaltando las Georgias, el mapa toma lugar fundamental. Se visibiliza la zona de guerra, la batalla entra -un poco sutil- en la mediatización de la guerra. Sin embargo, El Litoral no apela al mismo recurso, y el soldado en práctica de tiro vuelve a mostrarse en la tapa del mismo 26. Esta situación, al parecer contradictoria, nos entrega una pista interesante para entender lo que sigue: es el inicio de una formación desgajada del mundo posible que viene conformándose, que presentará, en todo momento, ciertas regularidades que se mantendrán constantes. Empero, estas regularidades dejarán colar dos representaciones que rozan al soldado como latigazos, pero que en realidad necesitan de la seguridad e inmovilidad que presentó el héroe desde el principio. Estos roces se hacen necesarios pues los acontecimientos de la guerra fáctica los impulsan: la muerte y la acción bélica concreta, ya que — sobre todo después de la caída del Belgrano- la muerte resonó con más fuerza y la llegada inglesa a Malvinas empezaba a tomar forma. Sin embargo, muerte y batalla se hicieron visibles desde formas atemperadas, respondiendo, de cierta forma, a la regularidad estática. Trataremos en las siguientes líneas de dar cuenta de nuestras afirmaciones. 


\section{Funerales/sobrevivientes y huellas/estrategias}

EI ARA General Belgrano, buque argentino de gran porte, fue hundido por el torpedo de un submarino inglés el 2 de mayo de 1982. La acción militar británica, en medio de potables propuestas de paz por los organismos que intentaban mediar en el conflicto, fue la medida bélica que más vidas cobró en el conflicto por el archipiélago del sur. Días después, la aviación argentina logra impactar sus misiles en el destructor HMS Sheffield, en la cual perecen más de 20 soldados del Reino Unido. A esta altura la guerra no tendría retorno.

El Litoral y Época publican la noticia de lo sucedido al buque argentino dos días después, el 4 de mayo, colocando la información en tapa. Ambos utilizan una imagen similar —un archivo del Belgrano-y resaltan que la acción del enemigo se efectuó fuera de la zona de exclusión, según lo resuelto por el Consejo de Seguridad. El mundo posible en torno a los soldados sumaría nuevos atributos, formas y desarrollos. Trataremos de dar cuenta de un particular referente que construye: los funerales/sobrevivientes, donde lo que se pone en juego es la representación de la muerte.

\section{Monumento al soldado invisible}

El 6 y el 10 de abril la muerte había entrado desde el diario Época. El día 6 se mostraban las fotos de dos jóvenes soldados muertos en la recuperación de las Georgias. Estos enunciados visuales individualizan a los muertos mediante el uso de fotografías tipo foto-carné, y las imágenes se acercan a las utilizadas en las secciones necrológicas de la prensa escrita. La foto-carné parece desdramatizar la escena mostrando los rostros adustos de los dos caídos. Esta individualización y desdramatización son una pequeña fisura a la forma en que luego tomará la muerte con el devenir de la guerra. El 10 de abril, Época nos entrega el sepelio de uno de los anteriores caídos, y el funeral militar monopoliza la representación. No veremos en toda la guerra los rostros de nuestros muertos, su espacio es ocupado por ataúdes, llantos y uniformes, ritual colectivo que aparta al muerto individual (esta última fotografía es la que marca el camino, donde el ritual militar, la madre/esposa en llanto y la simbología patriótica cubren a la muerte). Pero también tendrá lugar en la representación —sobre todo a partir de los acontecimientos del ARA General Belgrano- el sobreviviente, como muestra viva de los muertos. El héroe posible no morirá, no se mostrará su rostro; se mantendrá lejos del peligro.

En la edición del 3 de mayo, un día antes de la inflexión del hundimiento, El Litoral nos muestra un nuevo funeral, siendo la segunda imagen de esta línea antes de que se diera a conocer por la prensa escrita que el Belgrano había sido alcanzado por los misiles ingleses. El 6 de mayo aparecen, en las ediciones de ambos medios, las 
imágenes de los sobrevivientes del buque argentino torpedeado el primer día del mes Las tapas de El Litoral y Época nos muestran la misma fotografía: un soldado sonriente, abrazando a un superior. Litoral suma en su portada la formación de varias hileras de sobrevivientes, en orden militar, con sus brazos en la espalda. Época nos entrega los mismos tipos de fotos en el interior de la edición. Son rostros intactos, vigorosos, acompañados por oficiales que reconocen el valor del héroe. No hay remembranza, no hay recordación, ni siquiera las fotos-carné tienen lugar en el mundo posible.

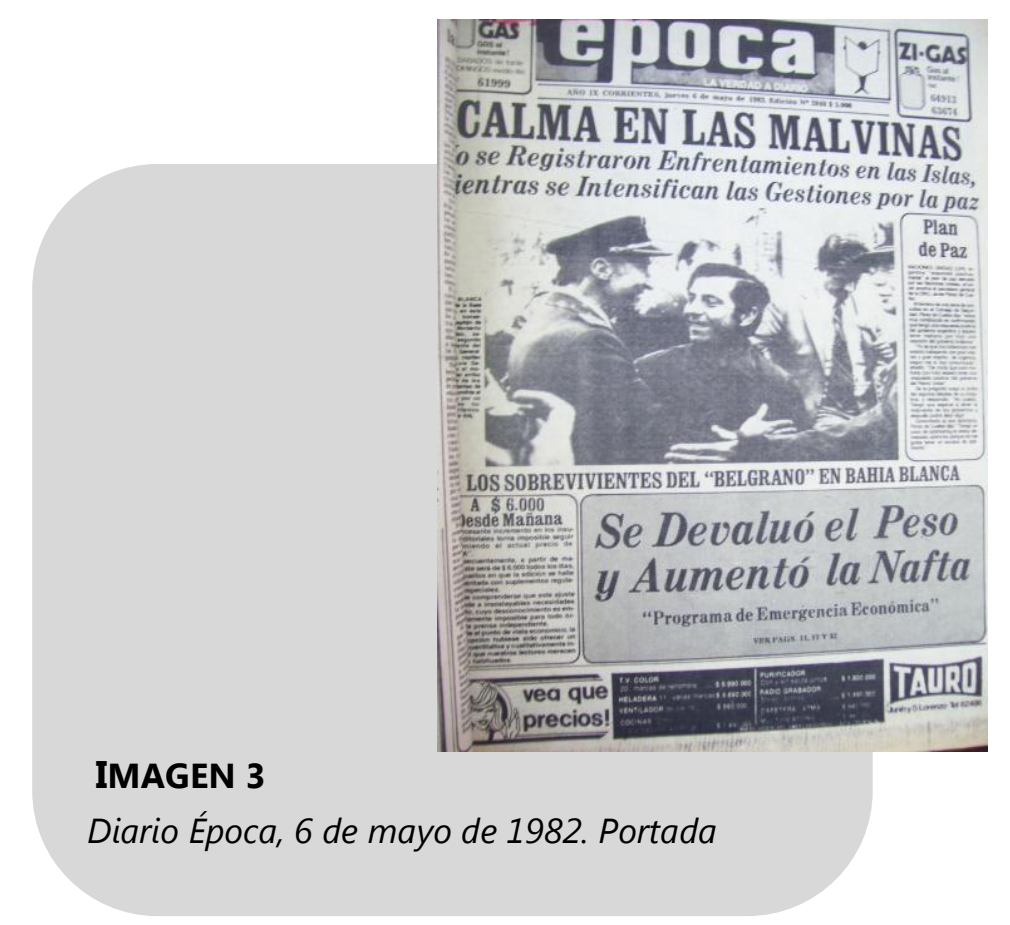

A mediado de mes las dos formas que cubren a la muerte proliferan, se encuentran y se cruzan, pero sobre todo agregan el contacto del pueblo con los sobrevivientes. Esta vez es la llegada de prisioneros de Georgias que vuelven al país. El pueblo los recibe con algarabía, los saluda, los toca, les obsequian escudos y banderas. Las tapas de El Litoral y Época del 14 de mayo nos entregan un colectivo con sobrevivientes sacando las manos por las ventanas, como si festejaran. El día 15 Época alcanza el clímax de no-muerte: la edición del día es dominada por funerales y llegadas. En la tapa vemos oficiales cargando un féretro; a la izquierda, saliendo de la ventanilla de un colectivo, un sobreviviente firma autógrafos. En el interior de la publicación vemos clarines, saludos militares y las condolencias oficiales a la viuda; también podemos apreciar abrazos, banderas y llantos de alegría por la llegada con vida de los héroes. Lo pasional de las imágenes pinta de emoción y ritualidad a la muerte.

Lo llamativo es que luego de esta fecha, la representación funerales/sobrevivientes tiende a desaparecer; la muerte casi no tiene lugar. El 19 de mayo ambos medios nos entregan la misma fotografía de un funeral militar inglés a un soldado argentino 
muerto en Georgias. Tendremos que esperar hasta los primeros días de junio para volver a ver sobrevivientes.

\section{IMAGEN 4}

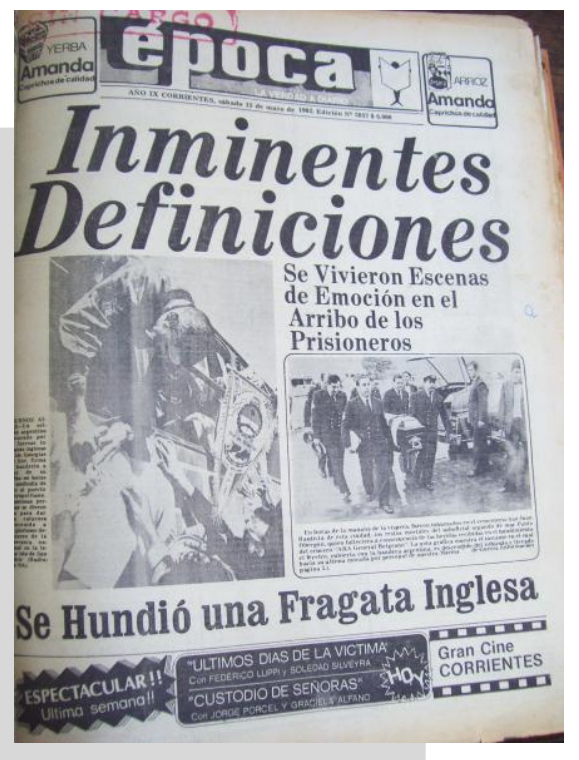

Diario Época, 15 de mayo de 1982. Portada

\section{El tramo final}

La regularidad que mantiene el mundo posible, que no perturba a nuestro estático héroe, se sostuvo en gran medida sobre la forma que tomó el soldado en el primer mes de conflicto. Esa forma estabilizada se mantiene como referente durante toda la guerra, y por eso se vuelve contradictoria al final. Esa guardia, desligada del presente de enunciación y con nula ligazón a un espacio preciso, irradia dominancia. Los nuevos atributos del mundo posible descansan sobre esa estabilización. ¿Por qué no hay muerte o batallas? Porque hay destino de grandeza y justicia.

Luego del 4 de mayo, el mundo posible se conformó sobre todo por enunciados visuales referentes a lo que analizábamos en apartados anteriores. Sin embargo, se entrelazaron algunas imágenes similares a las del primer mes: prácticas de tiro, uniformes, guardias, rondas, etc.

Podemos decir que después del hundimiento del Belgrano, hasta finales de mes cercano a Goose Green ${ }^{3}$ - el mundo posible visual se había diversificado agregando heterogeneidad a los elementos componentes. Pero al acercarnos al 28 de mayo, esos atributos heteróclitos tienden a homogeneizarse sobre la base del soldado estático, dominando nuevamente el mundo posible. Desde el 19 de mayo hasta la rendición, las imágenes de las prácticas militares de nuestros soldados dominan el mundo posible. El

3 Goose Green o Prado de Ganso fue una de las últimas batallas de la guerra de Malvinas. En esta se jugó el destino final del conflicto, ya que los ingleses ocuparon un lugar estratégico fundamental. 
Litoral y Época muestran la misma fotografía de dos soldados con un arma de gran tamaño. Ya no interesa el tiempo y lugar de esta imagen, las Malvinas como lugar de guerra se ha congelado, el mundo posible del soldado argentino, de las batallas, de la muerte, del héroe como institución social se repliega. A esta altura el lector correntino no tiene nada nuevo que ver, no se agregan elementos a su interpretación. El 25 de mayo ambos medios entregan este tipo de imagen en exclusividad, no se entrelazan las otras formas. Incluso se recupera al soldado como puro símbolo, tal como el día 3 de abril, cuando la tapa de Litoral nos entregaba la foto iwojimada. Una propaganda gubernamental entrega la romántica ilustración de un soldado sobre el mapa de Malvinas y un niño corriendo. Un rostro esperanzador, un estereotipo, la búsqueda del héroe.

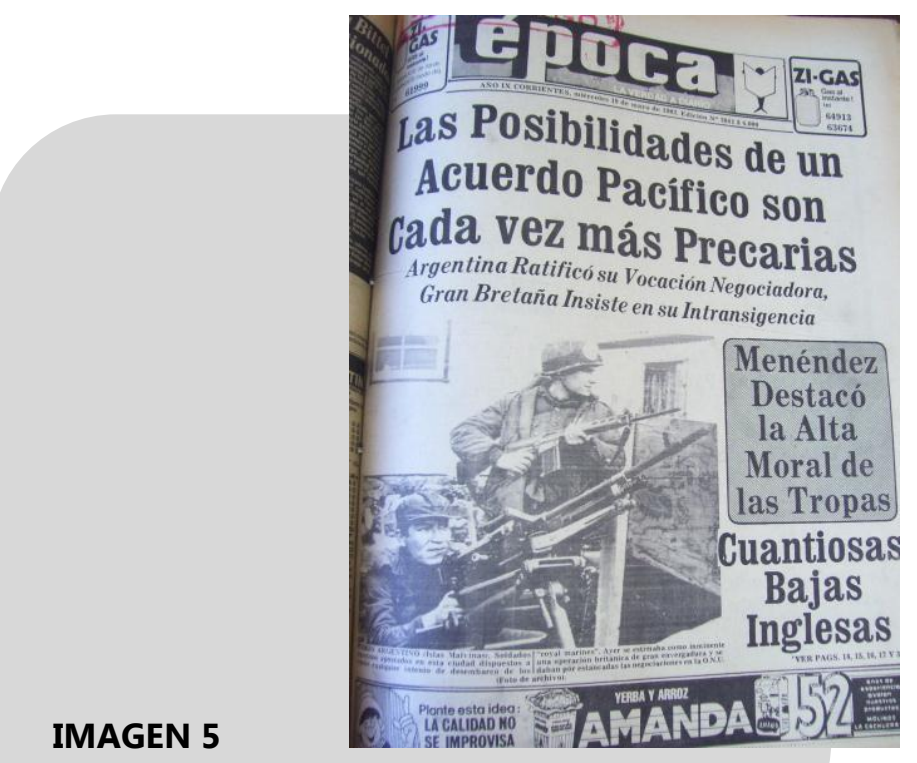

Diario Época, 19 de mayo de 1982. Portada

Ya pasado el 28 de mayo, el soldado argentino entrega sus últimas imágenes vivas, aunque cada vez más alejadas del presente de enunciación. Sin embargo, se vuelve necesario hacer una diferenciación, quizá la única que puede hacerse entre ambos periódicos. Época otorga cierto dinamismo al final de la guerra. Muestra heridos británicos, sobrevivientes del Narwall, guardia argentina y ejercicios tácticos (lo interesante es que aparece siempre indicada como de archivo por el epígrafe) hasta llegar a la rendición. Ese dinamismo viene acompañado de una disminución de la cantidad de fotografías. Es interesante ver cómo, luego de la llegada del papa el 11 y 12 de junio, vemos solo tres imágenes componentes del mundo posible: todas tienen a ingleses como protagonistas.

El Litoral, por su parte, regresa sobre la cierta convención idealizada de héroe; muestra dibujos, siluetas, enlaces históricos. Así el 28 de mayo, la valentía argentina se hace visible desde dos fotografías. En la primera, aparece una negra y anónima silueta 
de soldados cargando pertrechos; en la segunda, un dinámico salto de una práctica militar. La tapa del 29 sigue en esta línea, un soldado en un grito guerrero con un machete en mano. Un romántico soldado sosteniendo un ave y otro mezclado entre estereotipos de la sociedad, son las ilustraciones que marcan la unidad pueblo-héroe. Hasta el 6 de junio, el soldado argentino apareció de la misma forma. Luego desaparece y deberemos esperarlo hasta que pase la rendición.

\section{"Si Argentina entra en guerra, Corrientes le va a ayudar"}

El héroe correntino estuvo presente desde el comienzo de la guerra hasta el final y tuvo la particularidad de presentarse desde fotos íntimas. El soldado correntino es parte del héroe patriótico, pero se desprende sutilmente y se muestra individual. La foto intimista juega un papel fundamental en ello, los héroes locales emergen para ser mostrados al público correntino, en una unión familiar que otorga componentes nuevos al mundo posible del soldado de Malvinas.

El 3 de abril, el heroico correntino aparece al fulgor de la recuperación en el diario Época. Dos imágenes —unidas en sentido- muestran, por un lado, a un vigoroso marino y, por el otro, a sus ancianos padres. La madre se mostrará en varios lugares como otra heroína, conformando la unidad soldado/madre que constituirá una conjunción poderosa. En este atributo no podemos hablar de dinamismo o estaticidad, de espacio o de tiempo; no hay relato, pero sí remisiones. No podrían configurar un mundo posible, pero se hacen necesarios para la completitud del mundo que destacamos. El 7 de abril se presentan dos imágenes similares a la anterior. El soldado correntino ya se ha hecho un espacio.

\footnotetext{
$4 \quad$ Frase popular anónima. Se cree que proviene de las batallas libradas por miembros de las elites correntinas sobre caudillos locales bajo órdenes de Sarmiento.
} 


\section{IMAGEN 6}

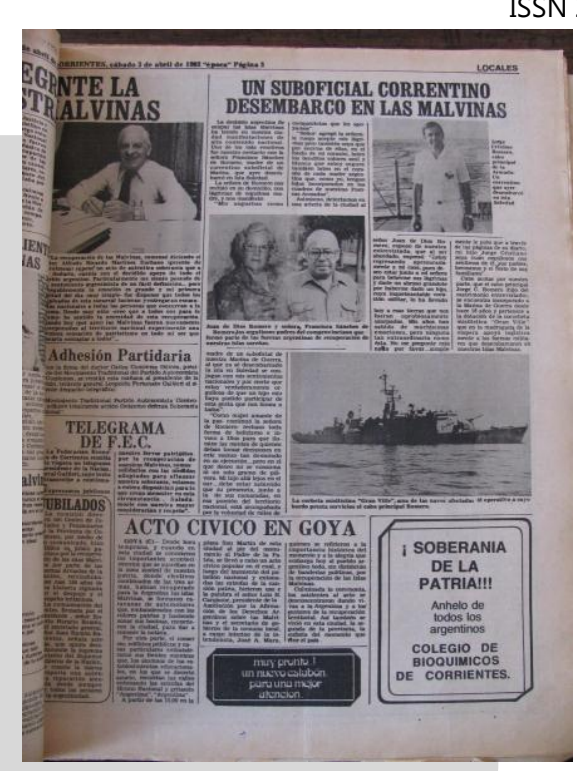

Diario Época, 3 de abril de 1982, página 3

Se agrega un elemento al héroe correntino, en un proceso de heroización general. Son jóvenes convocados que se presentan en la oficina militar. La imagen es una postal de tiempo: vemos camisas, jeans, bolsos, juventud. Pero en realidad lo que estas imágenes del 11 de abril nos muestran son soldados respondiendo al llamado de su destino, por eso son notables, noticiables, merecen ser mostrados desde este espacio. Protohéroes que dan cuenta de que —al menos hasta el 14 de junio- la juventud es valor, y el valor es correntino. En esta línea se encuentra la imagen, el 28 de abril, de un joven de 14 años que se anota como voluntario para ir al frente. Lo extraño es que esa juventud — que será el blanco de los ataques una vez finalizada la guerra- no merma sino que realza la valentía.

El Litoral da lugar al soldado correntino recién el 17 de abril, pero lo hace desde una de las mejores composiciones de la imaginería de la guerra. Son tres fotografías que muestran el rostro de un soldado con la cara pintada, dos mujeres mirando una revista, y por último, una de las mujeres sosteniendo la revista donde vemos publicada la primera fotografía. La mujer es la madre del soldado y en ese sostener se condensan grandes fuerzas de sentido. Como si fuera un cuento cortazariano, la última imagen no tiene inicio y fin, no tiene génesis de sentido ni descansa sobre piso firme. La madre sostiene al hijo, el hijo es una imagen, la imagen de un valiente. Ese sostener es sinónimo de amor, pero también es esperanza y ruego, la mujer lo sostiene como sostendría una imagen o figura religiosa. Esa esperanza se deposita en el valor de su hijo, pero también es la esperanza del regreso, un regreso con gloria por la victoria. Pero esa victoria se logrará por el valor, pero ese valor tiene un destino manifiesto. Pese a ese destino manifiesto, la madre espera al hijo con vida, pero lo muestra orgullosa porque él se está jugando la vida por la patria. No hay fin. 


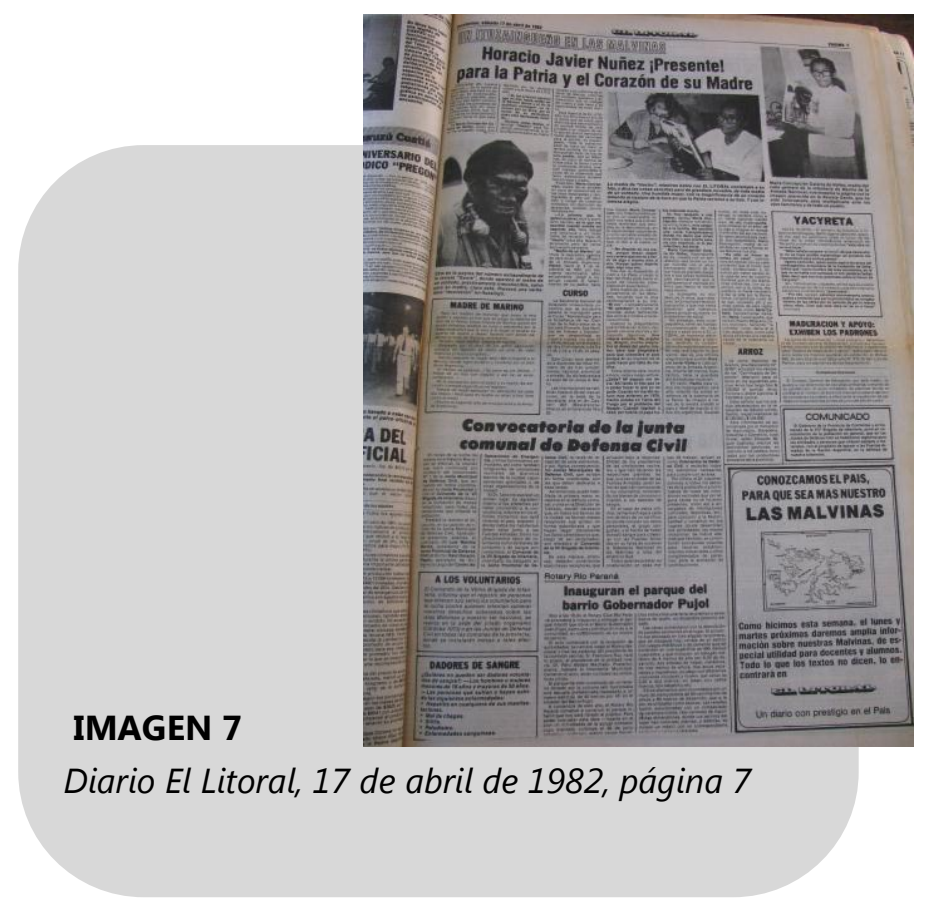

El 8 de mayo el héroe aparece como entrevistado. Un sobreviviente aparece abrazado a su familia o una foto amateur familiar muestra a un soldado aún en el frente. La conjunción familia/héroe siempre se manifiesta, la intimidad del heroísmo es parte de su visibilidad. El correntino sucumbe a Goose Green, que lo oculta hasta después de la rendición.

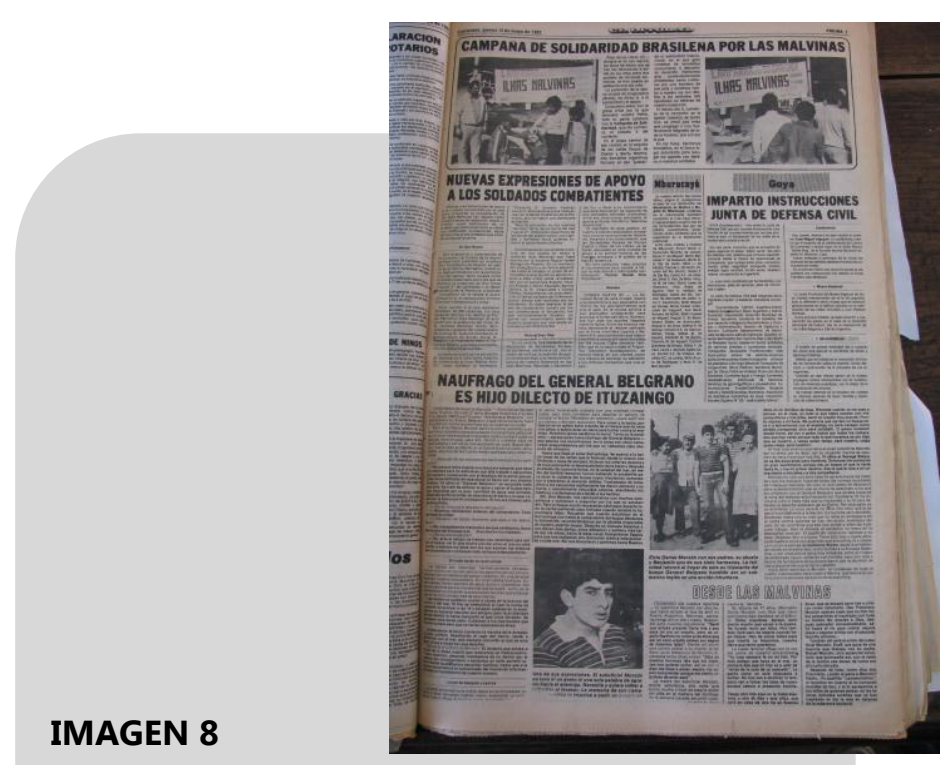

Diario El Litoral, 13 de mayo de 1982, página 7 


\section{La rendición}

El 14 de junio la guerra entre Argentina e Inglaterra por la soberanía de las islas Malvinas llega a su fin. El 14 y el 15, El Litoral y Época daban muestra de la incertidumbre y desinformación que existía en torno a la guerra. Las imágenes fueron ejemplo, ya que desaparece el héroe argentino por completo y es a través de los sobrevivientes y heridos ingleses como se muestra los acontecimientos en el archipiélago. Cuando la caída nacional toma conocimiento público, ambos diarios se parten en sus formas de enunciar mediante imágenes. El diario Época, medio que mostró con mayor entusiasmo a los correntinos en lucha, solo nos muestra una imagen del soldado correntino con su familia, apelando a la misma forma que antes lo hacía. Otras cuatro imágenes completan el pobre entramado iconográfico de Época luego del cese de hostilidades. Estas presentan fotos generales de sobrevivientes, manteniéndolo como ese signo de lo no muerto. El diario no puede romper con lo construido pese a la derrota, pero la rendición puede ser entendida como un punto de inflexión, es decir, como una marca en el tiempo ligada a algún hecho fáctico que tiene incidencia en el desarrollo discursivo. El Litoral llena de correntinidad a la rendición, muestra varias imágenes de correntinos sobrevivientes con sus familiares, llegando a sus respectivos pueblos, saludando a la gente. El soldado correntino no es tapado, se lo muestra con mayor entusiasmo y asiduidad que los 75 días de guerra en los medios. Se lo deja intacto, casi no aparecen imágenes de los soldados en otros puntos como en Época. Otro hecho curioso es que, luego de la derrota argentina, El Litoral muestra la primera imagen de llanto materno, cuando Época había dado mayor lugar a esta cuestión a lo largo de los días. Pese a estas puntualidades que marcan cambios en las formas de enunciar - modificaciones en la mirada del medio en cuanto a la guerra- podemos decir que la regularidad que se presentó desde el inicio se mantiene hasta el final. Los medios analizados necesitan de esa base para seguir enunciando, para seguir siendo verosímiles pese a las modificaciones más superficiales.

Lo último que marcaremos antes tiene que ver con otra particularidad que gira en torno a la rendición. Ambos medios, en algún punto cercano a la caída, dejaron de mostrar imágenes del soldado por varios días seguidos (de hecho en Época no aparecieron imágenes en los ejemplares del 16 y 17 de junio). El Litoral lo hizo desde el 7 de junio hasta el 15 — pasando por la visita del papa Juan Pablo II-; Época, por su parte, cerró sus ojos al héroe desde el 15 hasta el 21 de junio. Uno antes de la rendición y otro después, situación que descarta la imposibilidad de acceso a la imagen como factor. Desde nuestro punto de vista, este hecho se liga directamente con la operación del régimen escópico en las determinaciones editoriales. Son puntos donde parece insoportable mostrar al soldado desde las formas en que se lo normalizó. Como ya se dijo, el régimen escópico es inconsciente como todo Legein, por lo que no hablamos de una acción premeditada por parte de los medios, sino de regímenes de 
posibilidad de aparición que están trabajando en lo discursivo. El hecho de no mostrar está limitado por lo que se puede mostrar, ligados ambos a la codificación del Legein. Esta cuestión será retomada en nuestro análisis final, pero creímos importante adelantarla y ponerla en relación con el mundo posible mediático con el que hemos trabajado hasta aquí.

\section{La visibilidad: entre el imaginario y el régimen escópico}

Nuestra propuesta en este último tramo es reflexionar sobre las regularidades que hemos encontrado en el análisis previo, las cuales, como hemos dicho, son los indicios clave para entender la normalización representativa. Esa forma normalizada se liga al régimen escópico llevándonos por el camino del reconocimiento de las posibilidades de emergencia - lo visibilizable - y de las significaciones imaginarias que crean las condiciones de la representación tal como se da. Para ello nos centraremos en regularidades particulares que hemos identificado, las cuales nos servirán para dar cuenta de su posibilidad de emergencia y su referencia al imaginario social. Veremos qué se construyó del soldado de Malvinas desde los medios, qué nos dice esta construcción sobre el régimen de visibilidad y qué lazos encontramos a las significaciones imaginarias. Por último, reflexionaremos sobre esta visibilidad operando como nuevas condiciones en posguerra.

\section{El ojo materno: la visibilidad del héroe}

En el desarrollo de nuestro análisis resaltamos en varias oportunidades la construcción de un soldado estático, montado sobre la figura de la espera y la calma. No hay peligro para este soldado patriótico, pues no lo vemos cercano al conflicto. No se lastima, no muere. Esto no quiere decir que la muerte y la guerra no se hagan visibles, solo que esa visibilidad se torna ambigua, no toca al soldado. La muerte emerge tapada por ataúdes y por los sobrevivientes que desde su presencia muestran ausencias. La guerra se hace visible como índice de lo ocurrido o por ocurrir, es una marca que ha pasado o es el dedo que señala lo que pasará. Pero lo que pasa no se muestra.

Este teatro montado en torno al soldado pone en evidencia que lo que está en juego es una determinada representación del cuerpo. El cuerpo del héroe aparece a la vista todo el tiempo, no podemos dejar de verlo. Un cuerpo a salvo, erguido, fuerte; un rostro reconocible, admirable y tranquilo. La amenaza esconde el cuerpo, lo desvía. El cuerpo aparece desfasado ante el peligro, ya que otras formas ocupan su lugar: otros cuerpos, féretros, llantos. Es imprevisible la aparición de un cuerpo lastimado. Profundizando más en nuestras categorías diremos: un cuerpo en peligro no es visibilizable. 
Pero es necesario agregar un elemento más que está estabilizado en relación con lo que venimos desarrollando. Aparecen en los funerales imágenes de mujeres abrazadas al ataúd, llorando y recibiendo consuelo de las personas que las rodean. La figura materna y el féretro ocupan el lugar de ese cuerpo que no puede mostrarse: la madre recibe los restos de su hijo. Deja su lugar de espectadora y toma el lugar de protagonista, pues no tiene más que llorar al hijo que envió a morir por la patria. Se pone en juego la relación entre la mirada protectora de la madre - que ante la muerte corre en busca de su hijo- y la regular aparición del héroe estático. La mirada de la madre se convierte en prescripción, en vector de verosimilitud, ya que lleva a mostrar el cuerpo siempre presente y a salvo. De ahí las tapadas batallas o funerales, de ahí también el llanto que aparece llenando la ausencia o los sobrevivientes como viva imagen de los caídos. Estos héroes patrios devienen hijos cuyo cuidado aún está en manos de sus padres. El ojo materno quiere mirarlos, tenerlos a la vista. La fotografía es la imagen de que ese cuerpo vivo ha estado allí, y la repetición tipificada nos lleva a pensar que todos los cuerpos están tan a salvo como aquel se muestra. Los lazos de sangre patrióticos se hacen inteligibles en esa mirada protectora, que convierte a los medios en ventanas por donde los padres observan a sus hijos y se tranquilizan.

La patria como relación hereditaria crea las condiciones de aparición de este tipo de representación heroica. Guber (2001) afirma que la unidad de la sociedad ante la recuperación estuvo dada por lazos de parentesco y filiales. El molde desde el cual el gobierno dio forma y sustentó la credibilidad de su accionar se manifestó desde el lenguaje de la paternidad, suprimiendo las formas políticas. El gobierno de facto había colisionado otras maneras de participación, y es en la herencia familiar donde se hace teje la unidad argentina (pp. 38-43). Entonces el soldado y la patria se manifiestan indisolubles, siendo el hijo quien, a pesar del peligro, es enviado con orgullo por sus padres. Pero recordemos que la guerra y Malvinas son dos referentes desconocidos para los argentinos, por lo que se hace necesario no solo mostrar la falta de peligros, sino la relación armoniosa de los soldados con este lugar recuperado. Ver las prácticas de tiro, las trincheras, los paseos en Puerto Argentino son formas de suprimir el miedo de los padres. De esta forma la visibilidad del soldado tiene la longitud de la obsesiva mirada maternal.

\section{Un héroe moderno: correntinidad}

En concordancia con la reflexión de Verón, vimos el funcionamiento de la fotografía en cuanto a la modificación de lo público y lo privado. La sociedad, a través de la fotografía, consume públicamente imágenes de personas pertenecientes a ciertos estatus dados socialmente. Verón (1997) le asigna el nombre de notables, es decir, solo aquellos dignos de admirar tienen la legitimidad de fotografiar sus momentos privados 
para disfrute público. Lo notable en el discurso mediático deviene noticiable, es decir, digno de ser difundido como noticia, o, para ser más justos, verosímil.

Los soldados correntinos tienen ese lugar asignado, sus vidas — que están poniendo en juego- son dignas de ser mostradas. Sus rostros merecen ser fotografiados y sus palabras escuchadas. El soldado correntino es más que un héroe al alcance de la vista. Tiene un lugar de notabilidad, de excepcionalidad en la sociedad. Se establece una escisión entre el héroe de Malvinas y el héroe correntino en Malvinas, ya que este último aparece en fotos familiares o fotografiado por el diario con junto a miembros de su familia. No necesita ser cuidado por el ojo materno, los padres posan a su lado despreocupados. El soldado correntino es valiente, tiene tradición de coraje, es heredero de San Martín y Cabral, la sangre guaraní corre por sus venas. Estos lugares comunes posicionan concretamente a la imagen del soldado correntino como un héroe trascendente.

\section{Conclusión}

Nuestras conclusiones pretenden abrir nuevos interrogantes. Lo que se planteó en estas líneas fue una forma de lectura y una articulación teórica. Nuestro recorrido partió de una categoría general como régimen escópico, y pretendió enlazarse con una teoría del imaginario social, en cuya exhaustividad nos basamos para darle operatividad al régimen de visibilidad como prisma de análisis. En las relaciones entre régimen escópico y las significaciones imaginarias sociales que circulan en la sociedad, siempre cambiantes, pero siempre estables, encontramos el campo teórico adecuado para practicar una lectura. Esa lectura articuló a su vez herramientas propias de la semiótica y el análisis del discurso, para poder identificar un objeto discursivo (como los soldados de Malvinas) en un discurso social de prácticas narrativas (como el discurso de los medios de prensa, por ello utilizamos la noción clásica de mundos posibles), desde una materialidad significante como las imágenes (sobre todo la fotografía de prensa).

En nuestra lectura encontramos dos tipos de soldados: el estático y el notable; y solo el notable (correntino de nacimiento) sobrevivió al tabú de los primeros días posteriores a la rendición. Ese es el límite de nuestro acercamiento. Nos centramos en la visibilidad mediática de los soldados en el período correspondiente a la Guerra de Malvinas en dos periódicos correntinos. Pero nuestro intento pretende convertirse en un trabajo a largo plazo. Pretendemos internarnos en la inteligibilidad de los excombatientes correntinos en posguerra, su lucha simbólica y su lugar como objeto discursivo. Para Rosana Guber (2001), la invisibilidad de los veteranos respondió a una suerte de identificación de los soldados de Malvinas con la dictadura militar por parte de la sociedad. Y aunque eso es posible, hay semiosis que se han dejado de lado y necesitan leerse. 
¿Por qué estos hijos de la patria, y bravos y excepcionales correntinos pasaron a ser chicos de la guerra? ¿Cuál fue la guerra semiótica que tuvieron que enfrentar para su reconocimiento? Ahí, algunas preguntas sin respuestas; ahí, algunas condiciones para responderlas. 


\section{BIBLIOGRAFÍA}

Bajtín, M. (1995). Estética de la creación verbal. Buenos Aires: Siglo XXI.

Castoriadis, C. (1999). La institución imaginaria de la sociedad. $2^{\circ}$ Parte. Buenos Aires: Tusquets Editores.

Escudero, L. (1996). Malvinas: el gran relato. Fuentes y rumores de la información de guerra. Barcelona: Gedisa.

Jay, M. (2003). Campos de fuerza. Entre la historia intelectual y la crítica cultutral. Buenos Aires: Paidós.

Ledesma, M. (2005). Régimen escópico y lectura de imágenes. UNER. Disponible en http://www.fcedu.uner.edu.ar/clm/ledesma.html.

Narvaja De Arnoux, E. (2009). Análisis del discurso. Modos de abordar materiales de archivo. Buenos Aires: Santiago Arcos editor.

Rosa, C. (2011). Semiótica y visibilidad: recorridos de una tensión. En I Jornadas de Visualidad y Espacio: Imágenes y Narrativas. Paraná, UADER. 3 y 4 de octubre de 2011 (paper).

Verón, E. (1997). De la imagen semiológica a las discursividades. El tiempo de una fotografía. En: Veyrat-Masson, I. y Dayan, D. (1997). Espacios públicos en imágenes. Barcelona, Gedisa. 